\title{
MODEL PENINGKATAN KINERJA TENAGA PENJUAL : ORIENTASI PELANGGAN, KOMPETENSI TEKNIK TENAGA PENJUAL DAN PERILAKU PENJUALAN ADAPTIF
}

\author{
Sinar Hubtriyan Ade \\ Program Doktor Ilmu Manajemen, \\ UNISSULA, Semarang, Indonesia \\ Sinar.hubtriyan@gmail.com
}

\begin{abstract}
Adaptive sales behavior that is supported by the competence of salespeople is a variable built in order to bridge the influence between customer orientation on the performance of salespeople. In this study 102 salespeople at PT. Pelabuhan Indonesia III, (Persero), serve as a research population. The sampling technique used the census method or used the population as the research sample. This is done looking at the population that is in accordance with the minimum sample requirements in the use of SEM analysis tools (equitio modeling structure) The result of this research proves that customer orientation influence to adaptive selling behavior. the technical competence of salespeople influences adaptive sales behavior. Technical competence of salespeople does not affect the performance of salespeople and behavioral sales adaptive effect on the performance of salespeople
\end{abstract}

Keywords: customer orientation, technical competence of salespeople, adaptive sales behavior and performance of salespeople

\section{PENDAHULUAN}

Perusahaan yang bergerak dalam bidang penjualan produk, baik berupa barang ataupun jasa, tentunya akan memilih rangkaian bauran promosi yang tepat. Salah satunya adalah dengan mengaplikasikan personal selling. Hal ini berlaku baik bagi ranah business to consumer (B2C), ataupun ranah business to business (B2B). Sebagai salah satu dari bauran promosi, personal selling banyak digunakan oleh perusahaan yang menjual barang yaitu Personal selling menggunakan media sales force (tenaga penjual). Penyebab perusahaan memilih cara ini karena barang atau jasa yang ditawarkan tersebut membutuhkan cara menjual yang tidak umum dan tindakan pasca pembelian yang lebih intensif dibandingkan barang lain. Kinerja penjual mengacu pada prestasi finansial dan non finansial Dicapai oleh tenaga penjual individu sehubungan dengan peran dan tanggung jawabnya Ditetapkan oleh perusahaan. Ini menunjukkan seberapa baik kinerja tenaga penjual Tugas penjualannya terkait saat melaksanakan tanggung jawab pekerjaan yang ditugaskan (Kok-Leong Wong, 2016).

Orientasi pelanggan digadanggadang merupakan variabel yang dapat mempengaruhi peningkatan kinerja tenaga penjualan. Yu Ling Chen, (2006) mengemukakan bahwa orientasi pelanggan adalah kepercayaan organisasi untuk menempatkan keuntungan pelanggan di tempat pertama untuk mengembangkan profitabilitas jangka panjang. Lebih lanjut Yu Ling Chen, (2006) mengasumsikan bahwa peran orientasi pelanggan dalam industri jasa lebih penting dari pada industri lainnya, dan ini merupakan faktor penting dalam persepsi kualitas pelanggan. Hasil penelitian yang dilakukan Jose Varghese, 
(2015), Sara Kavoosi, (2014) dan Yu Ling Chen, (2006) membuktikan bahwa orientasi pelanggan berpengaruh signifikan terhadap kinerja tenaga penjual. Berbeda hasil dengan penelitian yang dilakukan Edward $E$. Rigdon, (2014) menjelaskan bahwa orientasi pelanggan tidak berpengaruh terhadap kinerja tenaga penjual. Berikut penjelasan lebih detail, pada tabel 1. research gap: pelanggan, mengembangkan strategi penjualan, mengevaluasi dampak dari pesan ini, dan melakukan penyesuaian (dalam presentasi penjualan) berdasarkan evaluasi ini. Sebenarnya, perilaku penjualan adaptif adalah kemampuan penjual untuk memenuhi operasinya dengan kebutuhan bersama pembeli (Keillor dan Parker, 2000 dalam Kavoosi, (2014).

Tabel 1. Research Gap

\begin{tabular}{|c|c|c|}
\hline Issue & Peneliti Terdahulu & Kesenjangan penelitian \\
\hline \multirow{4}{*}{$\begin{array}{l}\text { Pengaruh } \\
\text { orientasi } \\
\text { pelanggan } \\
\text { terhadap } \\
\text { kinerja } \\
\text { tenaga } \\
\text { penjual }\end{array}$} & $\begin{array}{l}\text { Sara Kavoosi, (2014) An Empirical } \\
\text { Investigation of the Impact of Customer } \\
\text { Orientation, adaptive selling behaviors, } \\
\text { and job satisfaction on salespeople's } \\
\text { performance: The Moderating Role of } \\
\text { Selling Experience }\end{array}$ & \multirow{3}{*}{$\begin{array}{c}\text { Customer orientation will be positively and } \\
\text { significantly affected to Job Performance } \\
\text { salespeople }\end{array}$} \\
\hline & $\begin{array}{l}\text { Yu Ling Chen, (2006) The Mediating } \\
\text { Effect of Knowledge Management } \\
\text { on Customer Orientation and Job } \\
\text { Performance of Salespeople }\end{array}$ & \\
\hline & $\begin{array}{l}\text { Jose Varghese, (2015) Perceived } \\
\text { Organizational Influences on Customer } \\
\text { Orientation and Sales Performance }-A \\
\text { Financial Services Industry Perspective }\end{array}$ & \\
\hline & $\begin{array}{l}\text { Edward E. Rigdon, (2014) Customer } \\
\text { orientation and salesperson performance }\end{array}$ & $\begin{array}{l}\text { Organizational customer orientation to } \\
\text { salesperson Performance non significant }\end{array}$ \\
\hline
\end{tabular}

Sumber : ringkasan hasil penelitian terdahulu, 2018

Pada tabel 1. dapat dilihat adanya research gap antara orientasi konsumen terhadap kinerja tenaga penjual, oleh karena itu variabel penghubung atau mediasi yang diangkat dalam penelitian ini adalah variabel perilaku penjualan adaptif, yang diharapkan dapat menjadi variabel intervening yang tepat untuk meningkatkan kinerja tenaga penjual. Hal ini didukung penelitian yang dilakukan Kok-Leong Wong, (2016) mendapatkan hasil bahwa perilaku adaptif berpengaruh signifkan dalam meningkatkan kinerja tenaga penjual.

Kavoosi, (2014) mendefinisikan perilaku penjualan adaptif seperti yang terdiri dari mengumpulkan informasi tentang calon
Dalam rangka untuk memperkuat perilaku penjualan adaptif dari tenaga penjual, maka variabel perilaku penjualan adaptif disokong dengan kompetensi tenaga penjual (seling skill), semakin tinggi kompetensi dari tenaga penjual, maka semakin berkualitas perilaku penjualan adaptif dari tenaga penjual. Keahlian tenaga penjualan merupakan pengetahuan khusus yang terkait dengan hubungan bisnis yang dimiliki dan Kemampuan seorang tenaga penjualan untuk memberikan solusi pada pelanggannya juga dapat menunjukkan tingkat keahlian tenaga penjualan tersebut (Liu \& Leach,2001 dalam Mulatsih, 2011:28 ). Hasil penelitian yang dilakukan Mulatsih, 
(2011) dan Kavoosi, (2014) mendapatkan hasil bahwa pengetahuan dari tenaga penjual dapat memperkuat pengaruh perilaku penjualan adaptif terhadap kinerja tenaga penjual.

Selain permasalahan penelitian tersebut, penelitian ini juga dilatar belakangi adanya fenomena yang terjadi di PT. Pelabuhan Indonesia III, (Persero) yaitu adanya penurunan pertumbuhan GDP Tahunan sebagaimana berikut :
Indonesia III, (Persero), maka pentingnya melakukan penelitian dengan tema kinerja tenaga penjual.

\section{TELAAH PUSTAKA DAN PENGEMBANGAN MODEL Kinerja Tenaga Penjual}

Kinerja tenaga penjualan menurut Baldauf et al.,(2001), adalah sebuah evaluasi dari kontribusi tenaga penjual terhadap pencapaian tujuan organisisasi. Menurut

Gambar 1. Pertumbuhan GDP Tahunan PT. Pelabuhan Indonesia III, (Persero)

PERTUMBUHAN GDP TAHUNAN

Annual GDP Growth

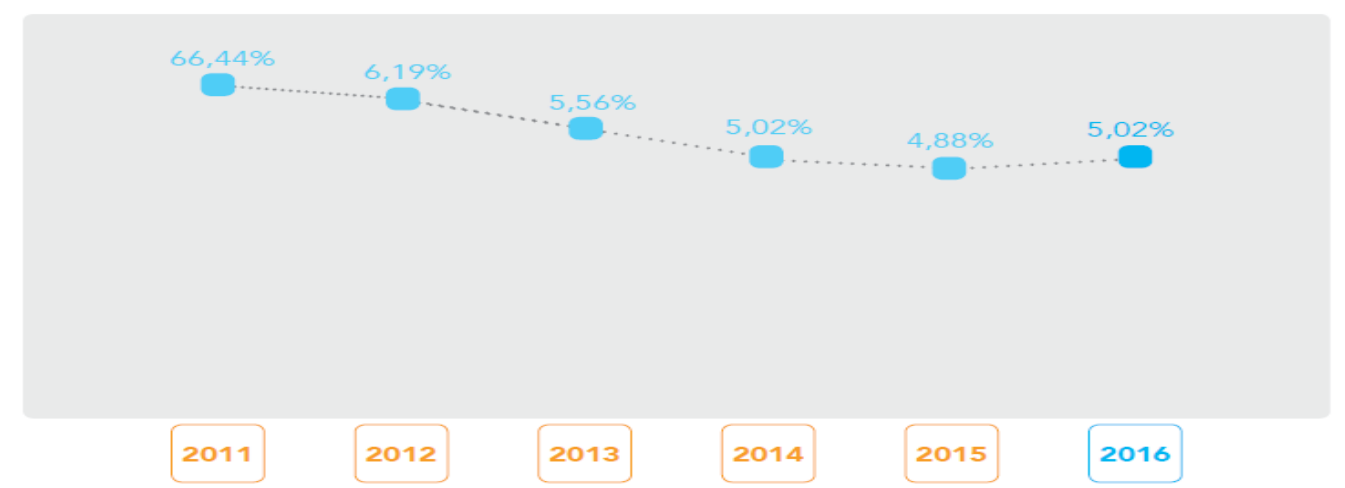

Sumber : Badan Pusat Statistik (BPS), 2018

Berdasarkan gambar diatas menunjukan bahwa pertumbuhan ekonomi global tahun 2016 tidak berjalan sebagaimana yang diharapkan. Meski masih mengalami pertumbuhan, namun dibandingkan tahun sebelumnya, pertumbuhan ekonomi global tahun 2016 cenderung lebih lambat. Perlambatan pertumbuhan ekonomi global pada tahun 2015 masih memberikan efek negatif dan mengakibatkan pertumbuhan ekonomi Indonesia di tahun 2016 sedikit terganggu. Secara tidak langsung penurunan GDP Tahunan ini disebabkan oleh kinerja tenaga penjual yang tidak optimal.

Berdasarkan uraian permasalahan penelitian dari riset-riset terdahulu dan adanya fenomena pada PT. Pelabuhan
Hidayah (2001), kinerja tenaga penjualan didefinisikan sebagai penilaian terhadap perilaku dalam bekerja. Bedasarkan paparan diatas dapat disimpulkan bahwa kinerja tenaga penjualan adalah evaluasi yang dilakukan sebagai bahan penilaian dalam pemenuhan target yang ditetapkan kepada tenaga penjual.

\section{Perilaku Penjualan Adapif}

Perilaku Penjualan Adapif merupakan kemampuan tenaga penjual untuk menggunakan pendekatan penjualan yang berbeda sesuai dengan situasi penjualan yang dihadapai serta jenis pelanggan yang ditemui (Indriani , 2005). Menurut Manske, et al., (2005) adaptivitas tenaga penjualan 
merupakan praktek dari mengubah suatu perilaku penjualan berdasarkan reaksi konsumen dan situasi alamiah dalam penjualan. Seorang tenaga penjualan dikatakan memiliki tingkat adaptivitas tenaga penjualan yang tinggi apabila dapat menggunakan pendekatan penjualan yang berbeda secara tepat pada saat transaksi dengan pelanggan dan pada saat membuat keputusan. Tingkat kemampuan menyesuaikan diri dari tenaga penjualan memerlukan tenaga kerja yang terampil dan terlatih cukup tinggi yang dapat menginterprestasikan situasi penjualan dan kemudian mengadopsikan taktik penjualan tersebut untuk kebutuhan-kebutuhan para konsumennya, yang meliputi merencanakan strategi penjualan yang khusus bagi konsumen yang berbeda-beda (Wardani 2002).

\section{Kompetensi Teknik Tenaga Penjual}

Menurut Ahmad (2010) kompetensi teknik tenaga penjualan (Technical Sales skill) merupakan salah satu keterampilan yang dimiliki tenaga penjual dalam rangka mendukung kegiatan penjualannya, keterampilan teknis misalnya seperti: pengetahuan mengenai informasi desain dan spesifikasidari produk, kemudian aplikasi dan fungsi dari produk yang ditawarkan kepada pelanggan. Pengetahuan tentang prosedur yang diberlakukan oleh perusahaan. Adanya keterampilan teknik, tenaga penjual mampu memberikan pelayanan yang memuaskan dan mampu meyakinkan pelanggan untuk membeli produk yang ditawarkan.

\section{Orientasi Pelanggan}

Orientasi pelanggan merupakan kemampuan tenaga penjual untuk berkomunikasi dengan pelanggan, dan usaha perusahaan untuk memahami keinginan dan kebutuhan pelanggannya (Sumber: Umar (2002). Orientasi pelanggan menurut Wahyudiono (2013) dapat dinyatakan melalui luasnya monitoring atas komitmen karyawan terhadap pelanggan atau pengembangkan strategi bersaing yang di dasarkan pada pemahaman atas kebutuhan serta pemahaman manajemen atas bagaimana bisnis dapat menciptakan customer value. Orientasi pelanggan menghasilkan sebuah logika yang lain yaitu sebagai hasil dari intensitas penggarapan kebijakan yang berorientasi pasar, perusahaan memiliki peluang untuk dapat membentuk persepsi pelanggan atas nilainilai yang dibangunnya dan nilai nilai yang dirasakan itu akan menghasilkan nilai kepuasan pelanggan.

\section{Hubungan Logis antar variabel dan Pengembangan Hipotesis Pengaruh orientasi pelanggan terhadap perilaku penjualan adaptif}

Fokus pelanggan mengutamakan pemahaman dan penerapan upaya pemenuhan kebutuhan dan keinginan pelanggan yang mendorong dilakukannya pengembangan hubungan kolaborasi jangka panjang. Dengan fokus pelanggan ini, memungkinkan perusahaan senang menghadapi keberhasilan mengeksploitasi perubahaan di pasar dengan mengembangkan produk yang lebih superior dari yang telah ada, dan dengan upaya untuk lebih fokus dan terintegrasi antar pendekatan fungsi untuk seluruh kegiatan pengoprasian Pemasaran menurut Adinoto (2012) harus memakai konsep bagaimana perusahaan mengetahui apa yang diinginkan pelanggan / konsumen dan memenuhinya dengan meletakkan kepuasan serta nilainilai pelanggan sebagai hal yang utama dan transaksi sebagai dasar analisis. Penelitian yang dilakukan Meiga kharisma, (2015) membuktikan bahwa orientasi pelanggan berpengaruh terhadap perilaku penjualan adaptif. Berbeda hasil dengan penelitian yang dilakukan Novitasari, (2016) bahwa orientasi pelanggan berpengaruh terhadap perilaku penjualan adaptif. Dari uraian diatas, maka hiptesis dalam penelitian ini yaitu : 
$\mathrm{H}_{1}$ : orientasi pelanggan berpengaruh terhadap perilaku penjualan adaptif

\section{Pengaruh kompetensi tenaga penjual terhadap perilaku penjualan adaptif}

Menurut Baldauf dan Cravens (2002) kemampuan teknik mengacu pada perilaku tenaga penjualan dalam menyediakan informasi tentang fitur dan spesifikasi produk serta penggunaan dan fungsi produk dan jasa. Tenaga penjualan juga harus mengetahui tentang industri dan trend yang sedang berkembang dimasyarakat seperti perkembangan pelanggan, perkembangan pasar, produk pesaing, kebijakan penjualan dan pengetahuan mengenai produk pesaing. Penelitian yang dilakukan Meiga kharisma, (2015) membuktikan bahwa kompetensi tenaga penjual (seling skill) berpengaruh terhadap perilaku penjualan adaptif. Berbeda hasil dengan penelitian yang dilakukan Wahyudi Hidayat, (2013) bahwa kompetensi tenaga penjual tidak berpengaruh terhadap perilaku penjualan adaptif. Dari uraian diatas, maka hiptesis dalam penelitian ini yaitu :

$$
\begin{array}{lll}
\mathrm{H}_{2}: & \begin{array}{l}
\text { kompetensi tenaga penjual } \\
\text { berpengaruh terhadap perilaku } \\
\text { penjualan adaptif }
\end{array}
\end{array}
$$

\section{Pengaruh kompetensi teknik tenaga} penjual terhadap kinerja tenaga penjual

Keahlian menjual juga digambarkan sebagai sebuah orientasi dari seseorang untuk berusaha melakukan perbaikan dan meningkatkan kemampuan serta penguasaan atas pekerjaan yang menjadi tanggungjawabnya. Arafat (2013), menyatakan bahwa keahlian dapat mempermudah dan membentuk sebuah pemahaman serta implementasi atas hubungan strategis antara perusahaan dengan konsumennya. Penelitian yang dilakukan Retno Mulatsih, (2011) dan Meiga kharisma, (2015) membuktikan bahwa kompetensi tenaga penjual (seling skill) berpengaruh terhadap kinerja tenaga penjual. Berbeda hasil dengan penelitian yang dilakukan Cristiana, (2014) bahwa kompetensi tenaga penjual tidak berpengaruh terhadap kinerja tenaga penjual. Dari uraian diatas, maka hiptesis penelitian ini yaitu:

$\mathrm{H}_{3}$ : kompetensi tenaga penjual berpengaruh terhadap kinerja tenaga penjual

\section{Pengaruh perilaku penjualan adaptif terhadap kinerja tenaga penjual.}

Bensi (2004) berpendapat bahwa tenaga penjual yang sukses adalah mereka yang dapat mengadaptasikan gaya komunikasinya secara tepat dalam interaksi dengan konsumen. Melalui teknik ini tenaga penjualan dapat mengamati bagaimana reaksi dari konsumen terhadap strategi penjualannya dan melakukan penyesuaian seperlunya (Manske, et al., 2005). Penelitian yang dilakukan Sara Kavoosi, (2014), Puji Lestari, (2015) dan Kok-Leong Wong, (2016) membuktikan bahwa perilaku penjualan adaptif berpengaruh terhadap kinerja tenaga penjual. Berbeda hasil dengan penelitian yang dilakukan cristiana,

\section{Gambar 2 Model Penilitian}

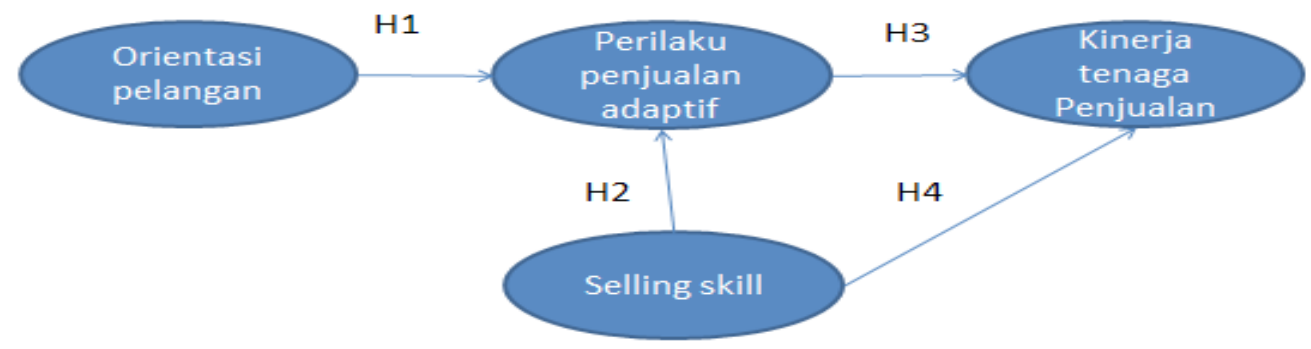


(2014) bahwa perilaku penjualan adaptif tidak berpengaruh terhadap kinerja tenaga penjual. Dari uraian diatas, maka hiptesis dalam penelitian ini yaitu :

$$
\begin{aligned}
\mathrm{H}_{4}: & \text { perilaku penjualan adaptif } \\
& \text { berpengaruh terhadap kinerja tenaga } \\
& \text { penjual }
\end{aligned}
$$

\section{Model Penilitian}

Model ini dibentuk berdasarkan telaah pustaka dan pengembangan hipotesis, sebagai gambar 2 .

\section{METODE PENELITIAN Populasi dan Sampel}

Populasi dalam penelitian ini adalah seluruh tenaga penjual di PT. Pelabuhan Indonesia III, (Persero), yang berjumlah 102 pegawai yang terdiri dari beberapa posisi, yaitu Manajer komersial, Asisten manajer pengembangan bisnis, Asisten manajer pemasaran, Asisten manajer penjualan, Asisten manajer bina pelanggan, supervisor dan staf marketing.

Melihat populasi yang cukup sesuai dengan persyaratan sampel minimal dalam penggunaan alat analisis SEM, maka teknik pengambilan sampel menggunakan metode sensus, atau keseluruhan tenaga penjual kecuali manajer komersial di PT. Pelabuhan Indonesia III, (Persero) dijadikan sampel penelitian.

\section{Metode Pengumpulan Data}

Teknik pengumpulan data yang digunakan dalam penelitian ini adalah kuesioner. Kemudian indikator itu menjadi titik tolak untuk menyusun item-item instrumen yang mempunyai gradasi dari sangat negatif sampai sangat positif.

\section{Uji Asumsi Analisis Jalur Uji Normalitas}

Uji normalitas dilakukan dengan uji skewness dan kurtosis baik secara univariate maupun multivariate. Jika nilai skewness dan kurtosis memiliki $p$-value yang lebih besar dari 0,05 baik pada uji univariate maupun pada uji multivariate. Hal ini menunjukkan bahwa model memiliki distribusi data yang normal (Ghozali, 2011)

\section{Kelayakan Model (Uji Goodness of Fit Test)}

Uji Goodness of fit test digunakan untuk melakukan pengujian kemaknaan model dalam menjelaskan hubungan antar variabel sebagaimana yang dihipotesiskan.

Analisis Jalur dan Pengujian Hipotesis

Model analisis jalur yang telah dilakukan dengan LISREL diperoleh nilai koefisien jalur model standardized dan nilai t hitung. Dari hasil pengujian tersebut dapat ditulis persamaan sebagai berikut :

Keterangan

$$
\begin{aligned}
& Y_{1}=\alpha+\beta_{1} X_{1}+\beta_{2} X_{2}+e \\
& Y_{2}=\alpha+\beta_{3} X_{2}+\beta_{4} y_{1}+e
\end{aligned}
$$

$\mathrm{Y}_{2}$ = kinerja tenaga penjual

$Y_{1}=$ perilaku penjualan adaptif

$\mathrm{X}_{1}=$ orientasi pelanggan

$\mathrm{X}_{2}=$ kompetensi teknik tenaga penjual

$a=$ konstanta

$\beta_{1}, \beta_{2}, \beta_{3}$ dan $\beta_{4}=$ koefisien regresi

Untuk menguji Hipotesis penelitian dengan uji t yaitu suatu uji untuk mengetahui signifikansi pengaruh variabel bebas secara parsial atau individual menerangkan variabel terikat. Pengujian dengan menggunakan dasar $\alpha=5 \%$ berarti hipotesis diterima (Ghozali, 2013)

\section{ANALISIS DATA DAN PEMBAHASAN Model Jalur}

Model analisis jalur yang telah dilakukan dengan LISREL diperoleh nilai koefisien jalur model standardized dan nilai $\mathrm{t}$ hitung. Dari hasil pengujian tersebut dapat ditulis persamaan sebagai berikut :

\section{Structural Equations:}

KTP $=0.72 * \mathrm{PPA}+0.2{ }^{*} \mathrm{KTTP}$, Errorvar.= $0.26, R^{2}=0.74$

PPA $=0.32^{\star} \mathrm{KTTP}+0.57^{*} \mathrm{OP}$, Errorvar. $=$ $0.38, R^{2}=0.62$ 


\section{Gambar 3 Uji Signifikansi - Standardized Estimates}

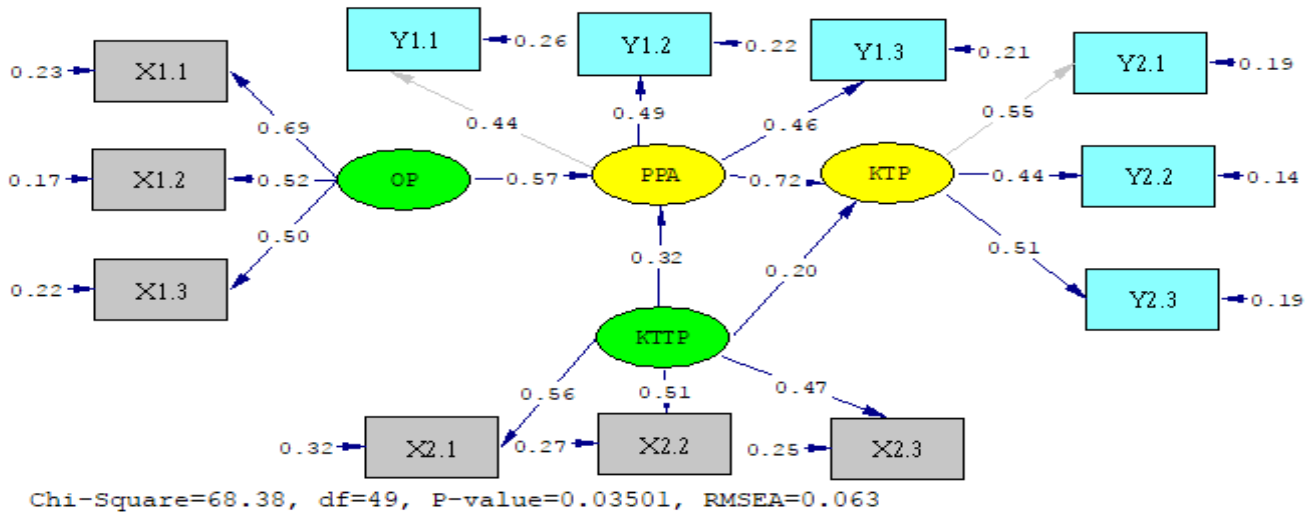

\section{Pengaruh Langsung:}

$\mathrm{PPA}=0.57 \mathrm{OP}+0.32 \mathrm{KTTP}$

$\mathrm{KTP}=0.72 \mathrm{PPA}+0.20 \mathrm{KTTP}$

\section{Pengaruh Tidak Langsung:}

$\mathrm{KTP}=\left(0.57 \mathrm{OP}^{*} 0.72 \mathrm{PPA}\right) \mathrm{OP}+(0.32$

KTTP*0.72 PPA) KTTP

$=0.42 \mathrm{OP}+0.43 \mathrm{KTTP}$

\section{Total Pengaruh :}

$\mathrm{KTP}=0.72+\left(0.57 \mathrm{OP}^{\star} 0.72 \mathrm{PPA}\right) \mathrm{OP}$

$+0.32\left(0.32 \mathrm{KTTP}^{*} 0.72 \mathrm{PPA}\right) \mathrm{KTTP}$

$=(0.72+0.42 \mathrm{OP})+(0.32+0.43 \mathrm{KTTP})$

$=1.14 \mathrm{OP}+0.75 \mathrm{KTTP}$

Berdasakan análisis jalur diperoleh semua koefisien variabel memiliki arah koefisien yang bertanda positif. Hasil ini dinterpretasi sebagai berikut : 1.) Orientasi pelanggan memiliki koefisien regresi ke arah positif terhadap perilaku penjualan adaptif. Hal ini menunjukkan bahwa semakin tinggi orientasi pelanggan maka semakin tinggi perilaku penjualan adaptif. 2). Kompetensi teknik tenaga penjual memiliki koefisien regresi ke arah positif terhadap perilaku penjualan adaptif. Hal ini menunjukkan semakin tinggi kompetensi teknik tenaga penjual maka semakin tinggi perilaku penjualan adaptif. 3). Kompetensi teknik tenaga penjual memiliki koefisien regresi ke arah positif terhadap kinerja tenaga penjual. Semakin baik kompetensi teknik tenaga penjual maka semakin tinggi perilaku penjualan adaptif. 4). Perilaku penjualan adaptif memiliki koefisien regresi ke arah positif terhadap kinerja tenaga penjual. Semakin banyak perilaku penjualan adaptif maka akan meningkatkan kinerja tenaga penjual.

\section{Gambar 4. Uji Signifikansi - Model T-Value}

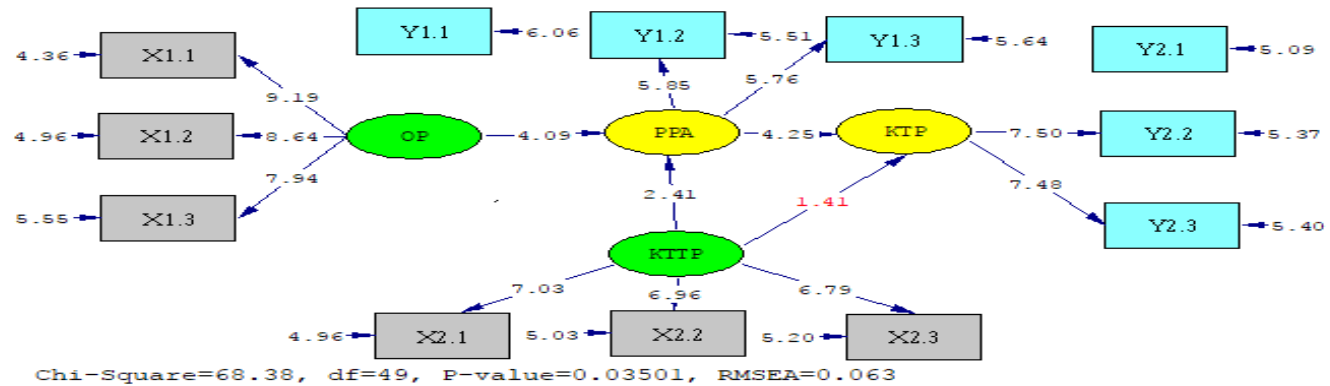


Pengujian Hipotesis

Untuk pengujian hipotesis untuk mengetahui pengaruh variabel bebas terhadap variabel terikat ada pada tabel 2 . menunjukkan jika nilai t value sebesar 4.25 $>1.96$, hal ini menunjukkan bahwa perilaku penjualan adaptif berpengaruh signifikan terhadap kinerja tenaga penjual yang artinya hipotesis diterima.

Tabel 2. Pengujian Hipotesis

\begin{tabular}{lcccc}
\hline \multicolumn{1}{c}{ Variabel } & $\begin{array}{c}\mathrm{T} \\
\text { Statistik }\end{array}$ & $>$ & T Value & Keterangan \\
\cline { 2 - 6 } $\begin{array}{l}\text { Orientasi pelanggan } \\
\text { adaptif }\end{array}$ & 4.09 & $>$ & 1.96 & Signifikan \\
$\begin{array}{l}\text { Kompetensi teknik tenaga penjual } \\
\text { perilaku penjualan adaptif }\end{array}$ & 2.41 & $>$ & 1.96 & Signifikan \\
\hline $\begin{array}{l}\text { Kompetensi teknik tenaga penjual } \\
\text { kinerja tenaga penjual }\end{array}$ & 1.41 & $>$ & 1.96 & Tidak Signifikan \\
\hline $\begin{array}{l}\text { Perilaku penjualan adaptif ' kinerja } \\
\text { tenaga penjual }\end{array}$ & 4.25 & $>$ & 1.96 & Signifikan \\
\hline
\end{tabular}

Sumber : data yang diolah, 2017

\section{Pengaruh Orientasi Pelanggan Terhadap Perilaku Penjualan Adaptif}

Berdasarkan pengujian hipotesis menunjukkan jika nilai $t$ value sebesar 4.09 $>1.96$, hal ini menunjukkan bahwa orientasi pelanggan berpengaruh signifikan terhadap perilaku penjualan adaptif yang artinya hipotesis diterima.

\section{Pengaruh Kompetensi Tenaga Penjual Terhadap Perilaku Penjualan Adaptif}

Berdasarkan pengujian hipotesis menunjukkan jika nilai t value sebesar 2.41> 1.96 , hal ini menunjukkan bahwa kompetensi teknik tenaga penjual berpengaruh signifikan terhadap perilaku penjualan adaptif yang artinya hipotesis diterima.

\section{Pengaruh Kompetensi Tenaga Penjual Terhadap Kinerja Tenaga Penjual}

Berdasarkan pengujian hipotesis menunjukkan jika nilai $t$ value sebesar $1.41<1.96$, hal ini menunjukkan bahwa kompetensi teknik tenaga penjual tidak berpengaruh signifikan terhadap kinerja tenaga penjual, artinya hipotesis ditolak.

\section{Pengaruh Perilaku Penjualan Adaptif Terhadap Kinerja Tenaga Penjual}

Berdasarkan pengujian hipotesis

Kelayakan Model (Goodness of Fit Test)

Uji goodness of fit test digunakan untuk melakukan pengujian kemaknaan model dalam menjelaskan hubungan antar variabel sebagaimana yang dihipotesiskan. Berikut adalah hasil uji goodness of fit test :

\section{Goodness of Fit Statistics}

Degrees of Freedom $=49$

Minimum Fit Function Chi-Square $=71.98$

$(\mathrm{P}=0.018)$

Normal Theory Weighted Least Squares

Chi-Square $=68.38(\mathrm{P}=0.035)$

Estimated Non-centrality Parameter (NCP)

$=19.38$

90 Percent Confidence Interval for NCP = $(1.51 ; 45.27)$

Berdasarkan hasil uji goodness of fit test didapatkan nilai chi square sebesar 71.98 dengan tingkat signifikansi $0,018<0,05$. Nilai estimasi NCP pada model sebesar 19.38 dan nilai confidence intervalnya adalah $1.51 ; 45.27$. Nilai tersebut termasuk nilai kecil sehingga dapat diartikan model berada pada katagori cukup baik.

\section{PEMBAHASAN}

Pengaruh Orientasi Pelanggan Terhadap Perilaku Penjualan Adaptif

Hasil pengujian hipotesis membuktikan secara empiris bahwa orientasi pelanggan 
berpengaruh signifikan terhadap perilaku penjualan adaptif. Hasil dari kuesioner terbuka menunjukkan bahwa responden Mampu memberikan kebutuhan pelanggan dan berusaha seoptimal mungkin untuk dapat memenuhinya sesuai dengan sistem dan prosedur yang berlaku di perusahaan. Dapat mencari informasi sebanyak mungkin terkait dengan pelanggan dan pesaing agar produk yang ditawarkan dapat sesuai dengan kebutuhan pelanggan dan pelanggan berpikir ulang jika akan berpindah kepada produk pesaing. Tenaga penjual diharapkan memiliki akses informasi yang luas dan baik untuk mengetahui situasi pelanggan, kondisi pasar serta produk pesaingnya.

\section{Pengaruh Kompetensi Tenaga Penjual Terhadap Perilaku Penjualan Adaptif}

Hasil pengujian hipotesis membuktikan secara empiris bahwa kompetensi teknik tenaga penjual berpengaruh signifikan terhadap perilaku penjualan adaptif. Hasil dari kuesioner terbuka menunjukkan responden memiliki pemahaman detail tentang produk yang ditawarkan, dan tenaga penjual juga dituntut untuk memiliki teknik yang baik dan cara yang berbeda dengan pesaing. Kompetensi teknik tenaga penjual lebih menitik beratkan kepada komunikasi, dimana dari komunikasi yang baik dan tepat maka pelanggan akan lebih mudah memahami produk yang ditawarkan. Teknik penjualan kepada masing-masing pelanggan tidak dapat disamaratakan, tergantung pada kondisi dan kebutuhan dari pelanggan yang sedang dihadapi, sehingga tenaga penjual dituntut untuk mencari informasi sebanyak mungkin mengenai pelanggannya.

\section{Pengaruh Kompetensi Teknik Tenaga Penjual Terhadap Kinerja Tenaga Penjual \\ Hasil pengujian hipotesis membuktikan secara empiris bahwa kompetensi teknik tenaga penjual tidak berpengaruh signifikan terhadap kinerja tenaga penjual. Hal ini menunjukan bahwa PT. Pelabuhan Indonesia III tidak begitu memperhatikan}

kompetensi teknik dari masing-masing tenaga penjual karena pekerjaan tenaga penjual cenderung memiliki tingkat resiko yang lebih rendah, sehingga perusahaan ini lebih bnyak menggunakan tenaga muda yang masih fress graduate agar berjalannya waktu pegawai tersebut dapat beradaptasi dan mengikuti pelatihan dan kesempatan belajar dari pekerjaan yang dijalankannya, sehingga kinerja tenaga penjualan dapat lebih berkembang.

Hasil dari kuesioner terbuka menunjukkan sebagian besar kemampuan yang dimiliki oleh tenaga penjual adalah sebatas pengetahuan tentang produk yang ditawarkan, sedangkan teknik penjualan serta pemahaman mengenai produk pesaing belum sepenuhnya diperhatikan, hal ini adalah salah satu penyebab kinerja tenaga penjual masih belum optimal. Oleh karena itu pegawai dituntut memiliki pengetahuan produk yang baik untuk ditawarkan kepada calon konsumen, memiliki pengetahuan yang baik tentang tipe pelanggan yang dihadapi, serta memiliki pengetahuan yang baik tentang produk pesaing. Retno Mulatsih, (2011) dan Meiga Kharisma, (2015) membuktikan bahwa kompetensi teknik tenaga penjual berpengaruh terhadap kinerja tenaga penjual.

\section{Pengaruh Perilaku Penjualan Adaptif Terhadap Kinerja Tenaga Penjual}

Hasil pengujian hipotesis membuktikan secara empiris bahwa perilaku penjualan adaptif berpengaruh signifikan terhadap kinerja tenaga penjual. Hasil dari kuesioner terbuka menunjukkan bahwa tenaga penjual yang adaptif akan dapat meningkatkan kepuasan pelanggan, karena pelanggan merasa kebutuhannya terpenuhi, termasuk juga adanya solusi yang tepat dari setiap permasalahan yang dihadapi. Dengan sikap adaptif yg dimiliki oleh tenaga penjual, maka pelanggan merasa lebih dihargai. Sikap adaptif tenaga penjual berpengaruh besar terhadap keputusan 
pelanggan untuk menggunakan produk layanan yang ditawarkan. Tenaga penjual akan memberikan suatu teknik pemuasan kebutuhan pada pelanggan karena mampu untuk mengenali setiap kebutuhan dan keinginan pelanggan yang berbeda-beda dan memberikan suatu alternatif pendekatan penjualan yang tepat untuk masingmasing situasi tersebut. Kemampuan untuk mengenali dan memenuhi kebutuhan pelanggan tersebut akan berdampak kepada kinerja tenaga penjualan.

\section{SIMPULAN}

Dalam rangka menjawab pertanyaan penelitian yang telah dibahas sebelumnya mengenai pengaruh orientasi pelanggan dan kompetensi teknik tenaga penjual terhadap perilaku penjualan adaptif, serta pengaruh dari kompetensi teknik tenaga penjual dan perilaku penjualan adaptif terhadap kinerja tenaga penjual, maka dapat disimpulkan bahwa : Orientasi pelanggan berpengaruh terhadap perilaku penjualan adaptif; Kompetensi teknik tenaga penjual berpengaruh terhadap perilaku penjualan adaptif; Kompetensi teknik tenaga penjual tidak berpengaruh terhadap kinerja tenaga penjual; Perilaku penjualan adaptif berpengaruh terhadap kinerja tenaga penjual.

Berdasarkan hasil pengujian yang telah diajukan, maka dapat ditarik implikasi teoritis yang disajikan sebagai berikut : Orientasi pelanggan berpengaruh terhadap perilaku penjualan adaptif

Hasil ini sejalan dengan teori menurut Narver (1990), untuk menciptakan "produk yang disukai pembeli" terus-menerus. Pemahaman di sini mencakup pemahaman terhadap seluruh rantai nilai pembeli baik pada saat terkini maupun pada saat perkembangannya dimasa yang akan datang.

Upaya ini dapat dicapai melalui proses pencarian informasi tentang pelanggan (Ucles, 2000). Dengan adanya informasi tersebut maka perusahaan akan memahami pelanggan potensialnya, baik pada saat ini maupun pada masa yang akan datang. Hasil ini sejalan dengan penelitian yang dilakukan Meiga Kharisma, (2015) membuktikan bahwa orientasi pelanggan berpengaruh terhadap perilaku penjualan adaptif.

Berbeda hasil dengan penelitian yang dilakukan Novitasari, (2016) bahwa orientasi pelanggan tidak berpengaruh terhadap perilaku penjualan adaptif. Kompetensi teknik tenaga penjual berpengaruh terhadap perilaku penjualan adaptif

Hasil ini sejalan dengan teori menurut Ahmad (2010) kompetensi teknik tenaga penjualan (technical sales skill) merupakan salah satu keterampilan yang dimiliki tenaga penjual dalam rangka mendukung kegiatan penjualannya, keterampilan teknis itu antara lain adalah pengetahuan mengenai informasi desain dan spesifikasi dari produk, aplikasi dan fungsi dari produk yang ditawarkan kepada pelanggan (penguasaan product knowledge), pengetahuan tentang prosedur yang berlaku di perusahaan. Hasil ini sejalan dengan penelitian yang dilakukan Meiga Kharisma, (2015) membuktikan bahwa kompetensi tenaga penjual (selling skill) berpengaruh terhadap perilaku penjualan adaptif.

Berbeda hasil dengan penelitian yang dilakukan Wahyudi Hidayat, (2013) bahwa kompetensi tenaga penjual tidak berpengaruh terhadap perilaku penjualan adaptif. Kompetensi teknik tenaga penjual tidak berpengaruh terhadap kinerja tenaga penjual

Hasil initidaksejalan dengan teorimenurut Baldauf dan Cravens (2002), kemampuan teknik mengacu pada perilaku tenaga penjualan dalam menyediakan informasi tentang fitur dan spesifikasi produk serta penggunaan dan fungsi produk dan jasa. Menurut Rentz et al.,(2002) Technical Sales Skill (keahlian teknik), adalah pengetahuan yang dimiliki tenaga penjualan dalam rangka mendukung penjualannya, seperti misalnya pengetahuan mengenai desain dan keistimewaan produk (menguasai 
product knowledge), pengetahuan tentang pemakaian dan fungsi produk, pengetahuan tentang teknik (keahlian engineering) dan prosedur yang diberlakukan oleh kebijakan perusahaan. Aspek keahlian tenaga penjual dalam aktivitas penjualan sebagai sebuah atribut dari tenaga penjual. Hasil ini sejalan dengan penelitian yang dilakukan Cristiana, (2014) bahwa kompetensi tenaga penjual tidak berpengaruh terhadap kinerja tenaga penjual.

Berbeda hasil dengan penelitian yang dilakukan Retno Mulatsih, (2011) dan Meiga kharisma, (2015) membuktikan bahwa kompetensi tenaga penjual (seling skill) berpengaruh terhadap kinerja tenaga penjual

Perilaku penjualan adaptif berpengaruh terhadap kinerja tenaga penjual. Hasil ini sejalan dengan teori menurut Bensi (2004) berpendapat bahwa tenaga penjual yang sukses adalah mereka yang dapat mengadaptasikan gaya komunikasinya secara tepat dalam interaksi dengan konsumen. Melalui teknik ini tenaga penjual dapat mengamati bagaimana reaksi dari konsumen terhadap strategi penjualannya dan melakukan penyesuaian seperlunya (Manske, et al., 2005). Penerapan adaptifitas oleh tenaga penjual menunjukkan kemampuan dan kecakapan tenaga penjual dalam melakukan teknik dan pendekatan tertentu secara tepat dengan memperhatikan kondisi dan situasi yang ada. Hasil ini sejalan dengan penelitian yang dilakukan Sara Kavoosi, (2014), Puji Lestari, (2015) dan Kok-Leong Wong, (2016) membuktikan bahwa perilaku penjualan adaptif berpengaruh terhadap kinerja tenaga penjual.

Berbeda hasil dengan penelitian yang dilakukan Cristiana, (2014) bahwa perilaku penjualan adaptif tidak berpengaruh terhadap kinerja tenaga penjual.

Berdasarkan hasil pengujian yang telah diajukan, maka dapat ditarik implikasi managerial yang disajikan sebagai berikut : 1). Orientasi pelanggan berpengaruh terhadap perilaku penjualan adaptif

Seoptimal mungkin dapat memenuhi kebutuhan pelanggan sesuai dengan sistem dan prosedur yang berlaku di perusahaan; Mencari informasi sebanyak mungkin terkait dengan pelanggan dan pesaing agar produk yang ditawarkan dapat sesuai dengan kebutuhan pelanggan dan pelanggan berpikir ulang jika akan berpindah kepada produk pesaing; Memiliki akses informasi yang luas dan baik untuk mengetahui situasi pelanggan, kondisi pasar serta produk pesaingnya. 2). Kompetensi teknik tenaga penjual berpengaruh terhadap perilaku penjualan adaptif

Memiliki pemahaman detail tentang produk yang ditawarkan; Memiliki teknik yang baik dan cara yang berbeda dengan pesaing; Kompetensi teknik tenaga penjual lebih menitik beratkan kepada komunikasi, dimana dari komunikasi yang baik dan tepat maka pelanggan akan lebih mudah memahami produk yang ditawarkan; Teknik penjualan kepada masing-masing pelanggan tidak dapat disamaratakan, tergantung pada kondisi dan kebutuhan dari pelanggan yang sedang dihadapi, sehingga tenaga penjual dituntut untuk mencari informasi sebanyak mungkin mengenai pelanggannya.

Perilaku penjualan adaptif berpengaruh terhadap kinerja tenaga penjual; Memiliki kemampuan adaptif dalam meningkatkan kepuasan pelanggan, karena pelanggan merasa bahwa kebutuhannya dapat terpenuhi, termasuk juga adanya solusi yang tepat dari setiap permasalahan yang dihadapi; Dengan sikap adaptif yang dimiliki oleh tenaga penjual, maka pelanggan merasa lebih dihargai.Sikap adaptif tenaga penjual berpengaruh besar terhadap keputusan pelanggan untuk menggunakan produk layanan yang ditawarkan dan akan berpikir ulang untuk menggunakan produk pesaing.

Berdasarkan nilai R square sebesar $74 \%$ dan $62 \%$ ditambah nilai estimasi NCP pada model sebesar 19.38 yang termasuk dalam kategori cukup baik. 


\section{DAFTAR PUSTAKA}

Ahmad, B. M. S \& Kitchen, P. J. 2010. The Relationship Between Sales Skil And Salesperson Performance And The Impact Of Organizational Commitment As Amoderator: An Empirical Study In A Malaysian Tellecomunications Company. International Journal Of Economic And Management.

Arafat, R. 2013. Pengaruh Dimensi Sales Skill Terhadap Kinerja Penjualan. Management Analysis Journal 2 (1)

Augusty Ferdinand. 2014, Metode Penelitian Manajemen Pedoman Penelitian untuk Penulisan Skripsi, Tesis, dan Disertasi IImu Manajemen, Edisi 3, AGF Books, Fakultas Ekonomika dan Bisnis Universitas Diponegoro, Semarang.

Baldauf, A., Cravens, D. W., \& Piercy, N. F. (2001). Examining Business Strategy, Sales Management, And Salesperson Antecedents Of Sales Organization Effectiveness. Journal of Personal Selling and Sales Management, 21(2), 109-122.

Baldauf, Artur, Cravens, David W (2002),"The Effect Of Moderators On The Salesperson Behavior Performance And Salesperson Outcome Performance And Sales Organization Effectiveness Relationship. (2002), European Journal of Marketing, Vol.36 No.11/12 p.1367-1388.

Edward E. Rigdon, Thomas G. Brashear. 2014. Customer Orientation And Salesperson Performance. Europan Journal of Marketing, Vol. 41, No. 7/8, pp. 821-835.

Ghozali, Imam. 2011. Aplikasi Analisis Multivariate dengan Program IBM SPSS 19. Semarang: UNDIP.

Ghozali, Imam (2009), "Model Persamaan Struktural Konsep Dan Aplikasi Dengan Program AMOS 16.0", Badan Penerbit Universitas Diponegoro, Semarang.

Girald, S. L., O'Keefe, J. M. F \& A. Price, M. A. 2012. Sales and Marketing. Solo: Tiga Serangkai. Husein Umar. 2002. Metode Riset Bisnis. Jakarta : PT. Gramedia.

Indriani, Farida 2005. "Analisis Program Manajemen Penjualan yang Berorientasi pada Konsultasi dalam Mempengaruhi Kinerja Tenaga Penjualan”. Jurnal Sains Pemasaran Indonesia. Vol. IV, No. 2, p.105-130.

Jose Varghese, Manoj Edward. 2015. Perceived Organizational Influences on Customer Orientation and Sales Performance - A Financial Services Industry Perspective. Journal of Marketing and Manajement, 6 (2), 11-21, Nov.

Kok-Leong Wong, Cheng-Ling Tan. 2016. Influence Of Supervisory Control On Salesperson Performance: Examining The Role Of Adaptive Selling Behaviour As A Mediator. Asian Academy of Management Journal, Vol. 21, No. 2, 183-203.

Liu, Annie H dan Mark P.Leach (2001),"Developing Loyal Customer with a Value Adding Sales Force: Examining Customer Satisfaction and The Perceived Credibility of Consultative sales people", Journal of Personal Selling \& Sales Management, Vol.2 (Spring), p.147156.

Meiga Kharisma, Ibnu Widiyanto. 2015. Anteseden Penjualan Adaptif Dan Pengaruhnya Terhadap Kinerja Tenaga Penjualan. Diponegoro Journal Of Management, Volume 4, Nomor 4, Halaman 1-13, ISSN (Online) : 2337-3792.

Narver, J.C. and Slater, S.F. (1990), "The effect of market orientation on business profitability", Journal of Marketing, Vol. 54, pp. 20-35.

Narver, J.C., Slater, S.F., (1994), Creating a Market Orientation, Journal of Market- Focused Management, Vol. 2, No. 3.

Puji Lestari, Sri Wartini. 2015. Pengaruh Technical Sales Skill Dan Non Technical Sales Skill Terhadap Kinerja Tenaga Penjualan Melalui Kepercayaan Konsumen Sebagai Variabel 
Intervening. Management Analysis Jornal, 4 (1), ISSN 2252-6552.

Rentz, Joseph O., C David Shepherd, Armen Taschian, Pratibha A. Dabholkar, and Robert T Ladd, (2002), "A Measuren of Selling Skill: Scale Development and Validation", Journal of Personal Selling and Sales Management, Vol.XXII, No.1 (Winter), p.13-21.

Retno Mulatsih. 2011. Studi Tentang Kinerja Tenaga Penjualan (Study of Performance of Sales Persons) Kasus Empiris Pada PT. Sinar Niaga Sejahtera Area Distribusi Jawa Tengah I. Fokus Ekonomi, Vol. 6, No. 1, Juni : 19-39.

Sara Kavoosi, Samaneh Sadeghian dan Kolsum Mahmudi. 2014. An Empirical Investigation Of The Impact Of Customer Orientation, Adaptive Selling Behaviors, And Job Satisfaction On Salespeople's Performance: The Moderating Role Of Selling Experience. International Journal of Research in Management, ISSN 2249-5908, Issue 4, Vol. 3 (May).

Setiobudi, Bayuaji Darus, 2007. "Analisis Faktor-faktor yang mempengaruhi Selling Skill Terhadap Kinerja Tenaga Penjualan". Jurnal Sains Pemasaran Indonesia. Vol. VII.

Sprio, R. L., \& Weitz, B. A., 1990. Adaptive selling: conceptualization, measurement, and nomological validity. Journal of Marketing Research, 27, 61-69.

Sugiyono. 2012. Memahami Penelitian Kualitatif. Bandung : ALFABETA.

Sujan, H., Weitz, B.A. and Kumar, N. (1994), "Learning orientation, working smart, and effective selling”, Journal of Marketing, Vol. 58, pp. 39-52.

Uncles, Mark. (2000). "Market Orientation". Australian Journal of Management.Vol.25,No.2.

Yu Ling Chen. 2006. The Mediating Effect of Knowledge Management on Customer Orientation and Job Performance of Salespeople. 